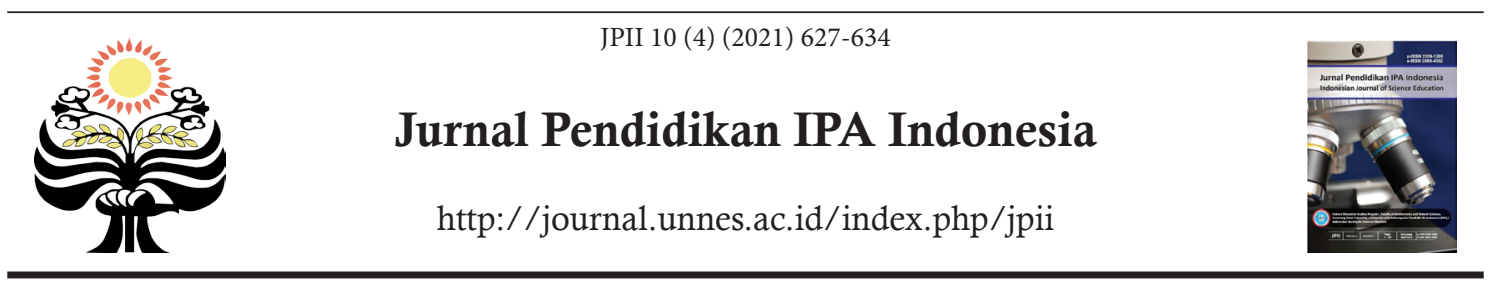

\title{
LEVEL OF ENVIRONMENTAL LITERACY OF STUDENTS AND SCHOOL COMMUNITY IN GREEN OPEN SPACE: IS THERE ANY DIFFERENCE BETWEEN BOTH OF THEM?
}

\author{
N. S. Putra*1, H. N. Sukma ${ }^{2}$ H. Setiawan ${ }^{3}$ \\ ${ }^{1}$ Universitas Pendidikan Indonesia, Indonesia \\ ${ }^{2}$ Institut Teknologi Bandung, Indonesia \\ ${ }^{3}$ Universitas Pendidikan Indonesia, Indonesia
}

DOI: 10.15294/jpii.v10i4.31083

Accepted: July $7^{\text {th }} 2021$. Approved: December $27^{\text {th }} 2021$. Published: December $31^{\text {st }} 2021$

\begin{abstract}
Environmental education aims to create people who have good environmental literacy. This study tries to explain previous studies related to how the level of students' literacy and stakeholders' literacy in green open space affects students' environmental literacy. This is descriptive research conducted in SMPN 2 Suayan. The purposes of this study are 1) to identify the environmental literacy of the students and the school community in the green open space; 2) to identify the difference between students' environmental literacy and school community in green open space. The sample consists of 70 students and 40 people from the school community. Measurement of environmental literacy is discussed in 3 domains, namely the domain of knowledge, attitudes towards the environment, and behavior towards the environment. The total number of instruments is 45 items. The reliability value of instruments for knowledge, attitude, and behavior domains are 0.874, 0.927, and 0.965, respectively, and are the high category. Collected data of students and school community were analyzed by using Microsoft Excel and SPSS. The difference in environmental literacy of students and school community in green open space was analyzed by using Mann-Whitney U Test. The environmental literacy value of students and school community are respectively $77.1 \%$ and $79.7 \%$ and are high category. The analysis on the achievement of environmental literacy scores shows that there are no significant differences in both groups. This concludes that the school community that has good environmental literacy will give a good influence on students' environmental literacy and knowledge. The last, by knowing the roles of the school community and availability of green open space on achieving environmental literacy of students, all related stakeholders are suggested to upgrade the environmental literacy of the school community and support the availability of green open space in the school area.
\end{abstract}

(C) 2021 Science Education Study Program FMIPA UNNES Semarang

Keywords: environmental education; green open space; environmental literacy; school community

\section{INTRODUCTION}

Education aims to transform people into better individuals in knowledge, attitudes, and behavior. The form of education that can change and give a huge impact on sustainable development is education for sustainable development (Tristananda, 2018). Sustainable development aims to achieve social progress, economic growth,

*Correspondence Address

E-mail: nandamursamad@upi.edu and peace (García-Feijoo et al., 2020). Jones et al. (2017) state that sustainable development's target is to solve environmental, economic, and social problems. According to Dube \& Lubben (2011), international society thinks that education for sustainable development means solving massive problems nowadays included environment, poverty, and health.

Similarly, environmental education seeks to change the human mindset and create people who have sensitivity to the environment. Envi- 
ronmental education is a term in the educational dimension as an environmental-based movement with a focus on environmental problems. Environmental education means (Shantini, 2016) teaching students related to environmental issues and environmental management insights.

According to Sudjoko (2014), environmental education means changing one's views and behavior towards the environment from a careless attitude to caring about the environment and so on, from being a passive observer turned into an active actor in environmental conservation efforts. Sukarto (2017) states that by knowing how important the character of environmental care is owned by everyone, it is very important to incorporate this environmental education into a formal education in Indonesia.

Rezkita \& Wardani (2018) state that in Indonesian environmental education programs are called Adiwiyata programs. In this context, education itself serves to build human beliefs, understanding, and ecological behavior (Maghfur, 2010), as well as to include affective aspects such as values, behaviors, commitment to building sustainable community life (Marliani, 2014). The importance of environmental education is to make people understand and competent to perform scientific performance and find solutions to environmental problems (Bonnett, 2010).

The main purpose of environmental education is to create people who have good environmental literacy and are sensitive to environmental problems. Then, Kusumaningrum (2018) states that environmental literacy means the ability of each individual to understand the environment and interpret the conditions in the environment and decide the right actions in addressing environmental problems. Environmental literacy is a measure of one's knowledge about human interaction with the environment, knowledge of environmental issues, and knowledge of various relationships that existed in ecological components. Nowadays, to see the massive environmental degradation, it is so urgent to educate people who are environmentally literate (Deswari \& Supardan, 2016). The positive relationship between human and nature is essential for solving today's environmental problems (Liefländer et al., 2013). Then, the core of environmental literacy is to know the questions about our world and our connection with it, to find the answers of these questions, and the way we apply and use all of these answers (Timur et al., 2013). The extent of individual environmental literacy can be reflected by the behavior with respect to the environment (Goldman et al., 2017)
Research conducted by Susilastri (2015) in schools that implement the Adiwiyata program finds that knowledge mastery and attitude towards the environment is still low. Some of the cases confirmed in the study are that the learning process does not demand the ability of the student's science process and family factors also affect the results of the student's low environmental literacy. This indicates that teachers need to take efforts harder to make the learning process more interesting, innovative, and environmentally oriented.

Many factors affect the profile of students' environmental literacy. Teachers play an important and responsible role in creating individuals and communities that are literate towards the environment (Tosun \& Gursakal, 2016). Science teachers should realize that science education has a huge impact on students' environmental literacy (Gayford, 2002). In addition, to support students' environmental literacy skills, environmentally related topics and issues must be included in the curriculum and textbooks, and the implementation of extra-curricular activities related to environmental literacy (Kaya \& Elster, 2019). By using textbooks containing topics about environment will provide opportunities for students to contribute actively in environmental maintenance (Curdt-Christiansen, 2021)

Furthermore, the location of the school located around the green open area will certainly support the students' environmental literacy indirectly. Following the concept of environmental education, the necessary learning environment should allow students to study outside the classroom, observe nature, practice learning issues about the environment (Desfandi, 2015). Mulyana (2009) argues that environmental education and the availability of a green school environment support students towards realizing, directing, and guiding towards the establishment of environmental ethics. Having that access to green open areas could improve environmental sensitivity. Later, a study conducted by Hammarsten et al. (2019) confirms that many children express positive feelings about forest gardens, carry out activities there, and care about living things there.

This study discusses the environmental literacy of students and the school community in a green open space. The idea is to identify the difference in environmental literacy possessed by students and the school community as part of school stakeholders. Indrati \& Hariadi (2016) state that all educational stakeholders have to think about sustainable education that is considered important for future life. There some urgencies 
of this study are: 1) to consider the influence of stakeholders to upgrade students' environmental literacy, therefore any policy can be made toward stakeholders to upgrade students environmental literacy; 2) to consider the influence of availability of green open space to upgrade students' environmental literacy, therefore any policy can be made toward availability of green open space to upgrade students' environmental literacy.

Based on the preliminary study, the research is located in an open green space. Then, the teacher in school practices environmental education in the learning process. This study tries to explain previous studies related to how the level of students' literacy and stakeholder's literacy in green open space affects students' environmental literacy. As stated that stakeholders have a very important role in the student's environmental literacy, so in the research, it is necessary to review the comparison of student and stakeholder literacy. The school stakeholders in this study are the school community. In fact, according to Maulidya et al. (2014), students' social life, culture, social background, parental, and any system in Indonesia still lack concern on environmental awareness.

Therefore, based on the background, there are two purposes of this study. Firstly, to identify the environmental literacy of the students and the school community in the green open space. Secondly, to identify the difference in environmental literacy of students and the school community in green open space. And the last, the limitations of the research are that the result of the research is only generalized in the school located in green open space, and the stakeholders involved in this research only consist of teachers and surrounding society. Other stakeholders can influence the environmental literacy of students.

\section{METHODS}

This is a type of descriptive research that aims to reveal the environmental literacy profile of students and the school community in a green open area. It was conducted to reveal the characteristics of the subjects. This study took place in SMPN 2 Suayan. SMPN 2 Suayan is a school located in a rural area with a green open environment. The location of the school is surrounded by hilly areas with forests that are still very shady and located in the surrounding rice fields and plantations. The strategic location of the school is very supportive of an effective environmental learning process. So, students are daily exposed to green open areas.

Samples are 70 students and 40 people from the school community. The school community consists of teachers, school employees, and the surrounding community. Students consist of grades VII, VIII, and IX. The school community means everyone who has a big possibility communicating with students. So, the researchers collected data from teachers, parents, students' neighbors, society around the school area. Domains of environmental literacy measured are knowledge, attitudes towards the environment, and behavior towards the environment. Table 1 shows the domains of environmental literacy.

Table 1. Domains of Environmental Literacy

\begin{tabular}{clcccc}
\hline No & Domains of Environmental Literacy & Items & Range Score & $\begin{array}{c}\text { Minimal } \\
\text { Score }\end{array}$ & $\begin{array}{c}\text { Maximal } \\
\text { Score }\end{array}$ \\
\hline 1 & Knowledge & 15 & $0-15$ & 0 & 15 \\
2 & Attitude toward environment & 15 & $15-60$ & 15 & 60 \\
3 & Behavior toward environment & 15 & $15-60$ & 15 & 60 \\
& $\quad$ Environmental Literacy & 45 & $30-135$ & 30 & 135 \\
\hline
\end{tabular}

McBeth \& Volk (2009)

The test is used to measure the knowledge domain of environmental literacy with a range score from 0 to 15 for each student. Non-test is to measure aspects of attitudes and behaviors of students and school community towards the environment with a range score from 15 to 60 for each student. The number of instruments of each domain is shown in Table 2. 
Table 2. Number of Instruments

\begin{tabular}{clllc}
\hline No & \multicolumn{1}{c}{ Variable } & Instrument & Output & Items \\
\hline 1 & Knowledge & Test & Score & 15 items \\
2 & Attitude toward environment & Questionnaire & Scale & 15 items \\
3 & Behavior toward environment & Questionnaire & Scale & 15 items \\
\hline
\end{tabular}

Domains of environmental literacy are adapted from Middle Schools Environmental Literacy Survey/ Instrument (MSELS/I) (NELA, 2008). The instruments used were validated by some experts from a different institution and then validated through an empirical test in a state school. The validation and reliability of instruments were analyzed by using SPSS software. The reliability value of instruments for the domains of knowledge, attitudes towards the environment, and behavior towards the environment are respectively $0.874,0.927$, and 0.965 and are categorized high. Then, questions and questionnaire items were chosen to be used in this research.

Data were collected by delivering the instruments to respondents. Data of students were collected in the school and data of school community were collected in the school and out of school randomly. The school community might consist of students' teachers, students' parents, students' neighbors, and other kinds of communities connected to students' daily life. Collected data of students and school community were analyzed by using Microsoft Excel and SPSS. To know the relationship between the school community and students, an average different test was conducted to see if there were differences in the results obtained by the two groups. Thus, it used the Mann-Whitney U test because the data distribution is abnormal. The result of the analysis is shown in percentage form.

The results of the environmental literacy test are processed in percentage form by using the following formula:

$$
N P=\frac{R}{S M} \times 100 \%
$$

Purwanto (2013)

Information:

$\begin{array}{ll}N P & =\text { Value } \%) \\ R & =\text { Score obtained by students } \\ S M & =\text { Maximal Score of Test }\end{array}$

The last, the results of the environmental literacy were interpreted in 3 categories. The environmental literacy categories are shown in table 3.

Table 3. Environmental Literacy Category

\begin{tabular}{cc}
\hline Range Score & Interpretation \\
\hline $22,2 \%-48,1 \%$ & Low \\
$48,2 \%-74,1 \%$ & Medium \\
$74,2 \%-100 \%$ & High \\
\hline
\end{tabular}

Interpretations of environmental literacy in three categories are low, medium, and high. The range score for the low category is $22.2 \%$ $48.1 \%$. The range score for the medium category is $48.2 \%-74.1 \%$. The range score for the high category is $74.2 \%-100 \%$.

\section{RESULTS AND DISCUSSION}

The result shows the environmental literacy of SMPN 2 Suayan students in the high category with an average score of $77.1 \%$. Based on these findings, it can be said that students have knowledge about a good environment, a good environmental care attitude, and good daily environmental practices. Table 4 shows environmental literacy scores for each domain studied.

Table 4. Score of Student's Environmental Literacy

\begin{tabular}{cccc}
\hline No & Domains & Percentage & Interpretation \\
\hline 1 & Knowledge & $66,6 \%$ & Medium \\
2 & Attitude & $83.3 \%$ & High \\
3 & Behavior & $81.3 \%$ & High \\
Environmental & $77.1 \%$ & High \\
\multicolumn{2}{l}{ Literacy } & & \\
\hline
\end{tabular}

In the researchers' observations, the high environmental literacy score obtained by students is at least influenced by two factors, namely: 1) the implementation of environmental education 
in schools; 2) students who are always exposed to green open spaces. These factors are believed by the researchers to greatly influence the literacy of students in SMPN 2 Suayan. These results are obtained through interviews with teachers and a survey on the school environment.

According to the teacher's statement that in the learning process teachers often associate with the surrounding environment. By associating learning with the surrounding environment, the learning process will be more real, and children will be easier to understand the learning material because what is discussed is what they find in everyday life. By being sensitive to the environment, the student's environmental literacy will increase. The use of examples that they directly find in everyday life such as discussion of forest areas found around them makes learning easier. Using the environment to educate is using all surrounding school environmental components to learn (Susanti \& Mulyani, 2013)

Furthermore, the role of green open areas as part of the daily environment of students at SMPN 2 Suayan also contributes to the students' literacy. As discussed earlier, SMPN 2 Suayan is located in a location surrounded by green areas, namely hills, forests, plantations, and rice fields. The school has ever been an Adiwiyata school and is currently expired. The school still maintains some facilities of Adiwiyata school. Being always exposed to green open space is one of the factors that support the high literacy of the students. This is in line with what Clark et al. (2016) said that to improve community environmental literacy, the understanding of green open spaces, availability and ease of access for people to green open spaces is one solution in achieving that goal. As suggested that environmental education is not only providing accurate information of nature but also giving access to nature in order to foster environmental knowledge, behavior and concern (Clayton et al., 2019). Then, a study of implementing field-based ecology class centered in local environmental socio-scientifc issue by learning outdoor can support environmental literacy competency of students (Kinslow et al., 2019). Thus, availability of green open space and access to nature in environmental education may foster environmental literacy of students.

The school community consists of teachers, school employees, and the community around the school. The profile of the environmental literacy of the community is needed to see the comparison of abilities possessed by students and the school community. The school community always interacts with the students both outside and inside the school. Based on data of environmental literacy tests of the school community, it was obtained that the percentage of achievement of environmental literacy of the school community is $79.7 \%$. This leads to the high category which means that the community of SMPN 2 Suayan school has good environmental literacy. This means that the environmental literacy possessed by both SMPN 2 Suayan students and the community is high.

Furthermore, based on 3 domains of environmental literacy that the percentage of environmental literacy of the school community in the domains of knowledge, attitudes, and behaviors are $74.3 \%, 85.5 \%$, and $79.3 \%$. More details can be seen in the table below.

Table 5. Environmental Literacy Score of the School Community

\begin{tabular}{cccc}
\hline No & Domains & Percentage & Interpretation \\
\hline 1 & Knowledge & $74,3 \%$ & High \\
2 & Attitude & $85.5 \%$ & High \\
3 & Behavior & $79.3 \%$ & High \\
Environmental & $79.7 \%$ & High \\
$\quad$ Literacy & & \\
\hline
\end{tabular}

Interpretation of environmental literacy in all three domains is high. The domain of knowledge is the lowest achievement owned by the school community. The school community is a part of stakeholders who play a very important role in the educational process in the school. The environmental literacy owned by the school community and students is at the same level which is in the high category. Therefore, the school community that has good environmental literacy will give a good influence on the environmental literacy of students. Stakeholders greatly influence the achievement of students' environmental literacy.

Teachers as part of stakeholders play an important role in the implementation of environmental education in schools (Liu et al., 2015). The successful of environmental education in educating well-informed students, environmentally responsible and aware citizens is committed by a teacher (Cheng \& So, 2015). Therefore, how teachers perceive environmental responsibility may effect their teaching (Aarnio-Linnanvuori, 2019). Thus, in the implementation of environmental education, teachers should already have good environmental literacy. In addition to teachers and school employees, the students' social environment is also very important in the achievement of students' environmental literacy. A social environment consisting of parents, relatives, 
and neighbors is an important part of shaping a student's environmental literacy. Afrianda et al. (2019) state that the attitude of caring about the environment is also influenced by the daily life of students who still get environmental education from both the family and the surrounding environment. In line with what Tamara (2016) says, family, residential environment, playmates, and relatives also greatly influence the environmental care attitude owned by students.

According to the research of Mustika \& Sahudra (2018) by conducting research on the role of the social environment in the formation of environmentally caring characters of geography students and it is obtained that the role of the family has the highest influence in the formation of environmentally caring characters followed by the role of the campus and the surrounding community. Then Perdana (2018) states that the role of parents/communities in character formation is as a figure in the implementation of characters. Therefore, the best way to shape students who have good environmental literacy is to carry out a good environmental education (Mardiani et al., 2020). However, the role of the school does not only form good literacy, but it needs support from the family and other social environments in the formation of good literacy. So as found in the study, literacy of the school community and students is at a high level. Thus, this is in line with previous discussions that student literacy is strongly influenced by the school environment and its social environment.

Furthermore, discussion on percentage comparison of the 3 domains of environmental literacy between students and the school community, there is a bit different in the percentage score of achievements. Based on Table 4 and Table 5, it can be seen that for the domain of knowledge, the percentage obtained by the school community is higher than students. Environmental literacy between students and the school community in the domain of knowledge where on students is in the medium category while on the community is in the high category.

Then, from the result, we know that the school community has better environmental knowledge than students. Then, for the attitude domain that the percentage owned by the school community is also higher than students with a relatively small difference. Both students and the community are at a high level. Furthermore, for the behavior domain, students have a higher percentage than the community with a relatively small difference. In general, both groups are in the high category of environmental literacy. Howe- ver, there is a difference in environmental literacy scores between the community and students where the community has higher score achievement than students. The difference in environmental literacy test scores between students and the community is about $2.6 \%$. This discussion has not explained whether there is a significant difference in the achievement of the environmental literacy test on students and the school community.

In the previous discussion, it has been stated that the school community affects the literacy of the students. This study finds that students and the community have high environmental literacy. To clarify the relationship between the two groups, an average different test was conducted to see if there were differences in the results obtained by the two groups. Thus, by using the Mann-Whitney U Test, it was obtained p-value > 0.05 . So, there is no difference in the average results of environmental literacy tests between students and the school community. This is concrete evidence that there is a very close relationship between the students and the school community.

The results of the research show that to raise the environmental literacy of students, it is needed to have a literate community. The community around the students affects students in many factors. The literate community supports literate kids and students. For example, teaching environmental education in school needs all teachers of all subjects who understand about environment. Because environmental education is not a subject of learning but integrated with other learning subjects (Afandi, 2013) including science, social, language, etc. So, we can say, to raise a literate student it needs a literate teacher. Teachers as part of a community are an important factor to build students' literacy. Building students' environmental literacy is important for ensuring environmental sustainability in a future life (Shume, 2016). Through this research, we can say that the government needs to upgrade the skills of the school community to build students' capability in environmental literacy. Environmental education in society level can be improved by efforts and contributions of governmental and non-gevernmental institutions and the environmental industries (Saribas et al., 2017).

\section{CONCLUSION}

SMPN 2 Suayan is a school located in a green open space surrounded by hills, forests, and rice fields. The results show that the environmental literacy of SMPN 2 Suayan students is at the high level with an average score of $77,1 \%$. Then, 
the results of the environmental literacy test on the school community present that the percentage of environmental literacy of the school community is $79.7 \%$ and categorized as high level. Next, Mann-Whitney U Test was implemented on these two data tested and known that these data do not differ significantly. This is concrete evidence that there is a very close relationship between the students and the school community. So, it is concluded that the school community that has good environmental literacy will give a good influence on the environmental literacy of students. Based on the findings of the study, implementing environmental education integrated with the surrounding environment is very effective to improve the environmental literacy of students. The school community that is literate to the environment has an important influence on the ability of students' environmental literacy. By knowing the roles of the school community and availability of green open space on achieving environmental literacy of students, all stakeholders especially government should upgrade the environmental literacy of the school community and support the availability of green open space in the school area. Through this research, we know that both stakeholder role and availability of green open areas in school support students' environmental literacy.

\section{ACKNOWLEDGMENTS}

The writer would like to deliver the greatest gratitude to the Indonesian Endowment Fund of Education (LPDP) (KET-1796/LPDP.4/2019) for the financial support.

\section{REFERENCES}

Aarnio-Linnanvuori, E. (2019). How do teachers perceive environmental responsibility?. Environmental Education Research, 25(1), 46-61.

Afandi, R. (2013). Integrasi Pendidikan Lingkungan Hidup Melalui Pembelajaran IPS di Sekolah Dasar Sebagai Alternatif Menciptakan Sekolah Hijau. PEDAGOGIA: Jurnal Pendidikan, 2(1), 98-108.

Afrianda, R., Yolida, B., \& Marpaung, R. R. T. (2019). Pengaruh Program Adiwiyata Terhadap Literasi Lingkungan dan Sikap Peduli Lingkungan. Jurnal Bioterdidik, Wahana Ekspresi Ilmiah, 7(1), 32-42.

Bonnett, M. (2010). Environmental education.In International Encyclopedia of Education (pp. 146-151). Elsevier.

Burchett, J. H. (2015). Environmental Literacy and its Implications for Effective Public Policy Formation.
Cheng, I. N. Y., \& So, W. W. M. (2015). Teachers' environmental literacy and teaching-stories of three Hong Kong primary school teachers. International Research in Geographical and Environmental Education, 24(1), 58-79.

Clark, D. G., Sorensen, A. E., \& Jordan, R. C. (2016). Characterization of factors influencing environmental literacy in suburban park users. Current World Environment, 11(1), 1.

Clayton, S., Bexell, S. M., Xu, P., Tang, Y. F., Li, W. J., \& Chen, L. (2019). Environmental literacy and nature experience in Chengdu, China. Environmental Education Research, 25(7), 1105-1118.

Curdt-Christiansen, X. L. (2021). Environmental literacy: raising awareness through Chinese primary education textbooks. Language, Culture and Curriculum, 34(2), 147-162.

Desfandi, M. (2015). Mewujudkan Masyarakat Berkarakter Peduli Lingkungan Melalui Program Adiwiyata. SOSIO DIDAKTIKA: Social Science Education Journal, 2(1), 31-37.

Deswari, N., \& Supardan, D. (2016). Upaya peningkatan environmental literacy peserta didik di sekolah adiwiyata (Studi inkuiri naturalistik di SD Negri 138 Pekanbaru). Jurnal Socius, 5(2).

Dube, T., \& Lubben, F. (2011). Swazi teacherse views on the use of cultural knowledge for integrating education for sustainable development into science teaching. African Journal of Research in Mathematics, Science and Technology Education, 15(3), 68-83.

García-Feijoo, M., Eizaguirre, A., \& Rica-Aspiunza, A. (2020). Systematic review of sustainabledevelopment-goal deployment in business schools. Sustainability, 12(1), 440.

Gayford, C. G. (2002). Environmental literacy: Towards a shared understanding for science teachers. Research in Science and Technological Education, 20(1), 99-110.

Goldman, D., Pe'er, S., \& Yavetz, B. (2017). Environmental literacy of youth movement members-is environmentalism a component of their social activism?. Environmental Education Research, 23(4), 486-514.

Hammarsten, M., Askerlund, P., Almers, E., Avery, H., \& Samuelsson, T. (2019). Developing ecological literacy in a forest garden: children's perspectives. Journal of Adventure Education and Outdoor Learning, 19(3), 227-241.

Indrati, D. A., \& Hariadi, P. P. (2016). Esd ( Education for Sustainable Development ) Melalui Pembelajaran Biologi. In Symposium on Biology Education (371-382).

Jones, P., Wynn, M., Hillier, D., \& Comfort, D. (2017). The Sustainable Development Goals and Information and Communication Technologies. Indonesian Journal of Sustainability Accounting and Management, 1(1), 1-15.

Kaya, V. H., \& Elster, D. (2019). A critical consideration of environmental literacy: Concepts, contexts, and competencies. Sustainability (Switzerland), 11(6). 
Kinslow, A. T., Sadler, T. D., \& Nguyen, H. T. (2019). Socio-scientific reasoning and environmental literacy in a field-based ecology class. Environmental Education Research, 25(3), 388-410.

Kusumaningrum, D. (2018). Literasi Lingkungan Dalam Kurikulum 2013 Dan Pembelajaran Ipa Di Sd. Indonesian Journal of Natural Science Education (IJNSE), 1(2), 57-64.

Liefländer, A. K., Fröhlich, G., Bogner, F. X., \& Schultz, P. W. (2013). Promoting connectedness with nature through environmental education. Environmental education research, 19(3), 370-384.

Liu, S. Y., Yeh, S. C., Liang, S. W., Fang, W. T., \& Tsai, H. M. (2015). A national investigation of teachers' environmental literacy as a reference for promoting environmental education in Taiwan. The Journal of Environmental Education, 46(2), 114-132.

Maghfur, M. (2010). Pendidikan lingkungan hidup dan masa depan ekologi manusia. In Forum tarbiyah (Vol. 8, No. 1, pp. 57-71). Fakultas Tarbiyah IAIN Pekalongan.

Mardiani, N. D., Husamah, H., Fatmawati, D., Miharja, F. J., \& Fauzi, A. (2020). Literasi Lingkungan Melalui Pendidikan Lingkungan di Masa Pandemi Covid-19. In Prosiding Seminar Nasional Pendidikan Biologi.

Marliani, N. (2015). Pemanfaatan limbah rumah tangga (sampah anorganik) sebagai bentuk implementasi dari pendidikan lingkungan hidup. Formatif: Jurnal Ilmiah Pendidikan MIPA, 4(2).

Maulidya, F., Mudzakir, A., \& Sanjaya, Y. (2014). Case study the environmental literacy of fast learner middle school students in Indonesia. International Journal of Science and Research, 3(1), 193197.

McBeth, W., \& Volk, T. (2009). The national environmental literacy project: A baseline study of middle grade students in the United States. The Journal of Environmental Education, 41(1), $55-67$.

Mulyana, R. (2009). Penanaman Etika Lingkungan Melalui Sekolah Perduli dan Berbudaya Lingkungan. Jurnal Tabularasa, 6(2), 175-180.

Mustika, F., \& Sahudra, T. M. (2018). Peranan Lingkungan Sosial terhadap Pembentukan Karakter Peduli Lingkungan Mahasiswa Pendidikan Geografi di Universitas Samudra Langsa. JUPIIS: Jurnal Pendidikan Ilmu-ilmu Sosial, 10(2), 235-244.

National Environmental Literacy Assessment (NELA). (2008). Final Research Report Part 1 \& 2. Washington DC: Nela Project

Perdana, N. S. (2018). Implementasi peranan ekosistem pendidikan dalam penguatan pendidikan karakter peserta didik. Refleksi Edukatika: Jurnal Ilmiah Kependidikan, 8(2).
Purwanto, N. (2013). Prinsip-Prinsip Evaluasi Pengajaran. In Bandung: PT Remaja Rosdakarya.

Rezkita, S., \& Wardani, K. (2018). Pengintegrasian Pendidikan Lingkungan Hidup Membentuk Karakter Peduli Lingkungan di Sekolah Dasar. TRIHAYU: Jurnal Pendidikan Ke-SD-a,n 4(2), 327-331.

Saribas, D., Kucuk, Z. D., \& Ertepinar, H. (2017). Implementation of an environmental education course to improve pre-service elementary teachers' environmental literacy and self-efficacy beliefs. International Research in Geographical and Environmental Education, 26(4), 311-326.

Shantini, Y. (2016). Penyelenggaraan Efsd Dalam Jalur Pendidikan di Indonesia. Pedagogia Jurnal Ilmu Pendidikan, 13(1), 136-141.

Shume, T. (2016). Teachers' Perspectives on Contributions of a Prairie Restoration Project to Elementary Students' Environmental Literacy. International Journal of Environmental and Science Education, 11(12), 5331-5348.

Sudjoko, S. (2014). Perkembangan dan konsep dasar pendidikan Lingkungan Hidup. Pendidikan lingkungan hidup, 1(1), 1-4.

Sukarto, S. (2017). Pendidikan karakter peduli lingkungan: Studi Multikasus di MIN Tegalasri Wlingi Blitar dan SDN 1 Sukun Kota Malang (Doctoral dissertation, Universitas Islam Negeri Maulana Malik Ibrahim).

Susanti, N. D., \& Mulyani. (2013). Memanfaatkan Lingkungan Sekitar Sebagai Sumber Belajar Dengan Tema Lingkungan Untuk Meningkatkan Hasil Belajar Siswa Kelas III Sekolah Dasar. Jurnal Penelitian Pendidikan Guru Sekolah Dasar, 1(2), 1-11.

Susilastri, S. D. (2015). Students' environmental literacy profile in school-based nature and in school that implement the adiwiyata program. Prosiding KPSDA, 1(1).

Tamara, R. M. (2016). Peranan lingkungan sosial terhadap pembentukan sikap peduli lingkungan peserta didik di SMA Negeri Kabupaten Cianjur. Jurnal Geografi Gea, 16(1), 44-55.

Timur, S., Timur, B., \& Yilmaz, S. (2013). Determining primary school candidate teachers' levels of environmental literacy. The Anthropologist, 16(12), 57-67.

Tosun, E. K., \& Gursakal, S. (2016). Environmental Literacy Levels of The Classroom Teachers In Turkey. The Online Journal of New Horizons In Education, 6(3), 33-59.

Tristananda, P. W. (2018). Membumikan Education for Sustainable Development (Esd) Di Indonesia Dalam Menghadapi Isu - Isu Global. Purwadita: Jurnal Agama Dan Budaya, 2(2), 42-49. 